\title{
Recenzja
}

\section{Krzysztof Grajewski, Odpowiedzialność postów i senatorów na tle zasady mandatu wolnego, Wolters Kluwer Polska, Warszawa 2009, ss. 446.}

Za przedmiot monografii Autor obrał problematykę sensu largo rozumianej odpowiedzialności parlamentarzysty w Polsce współczesnej. Powiązał ją $\mathrm{z}$ zasadą mandatu wolnego. Już w tym miejscu podkreślić należy trafność i znaczenie doboru badanych zagadnień. $Z$ jednej strony formy odpowiedzialności parlamentarzysty, z drugiej zaś strony problematyka mandatu przedstawicielskiego, składają się na istotę wszelkich systematycznych rozważań o prawie parlamentarnym. Znakomicie korespondują z podnoszonym w piśmiennictwie naukowym postulatem skoncentrowania potencjału intelektualnego wokół jednego z najtrudniejszych dylematów współczesnego parlamentaryzmu, jakim jest współegzystowanie koncepcji mandatu wolnego z praktyką polityczną podporządkowującą piastuna mandatu gremiom partyjnym. Jak pisze Autor przedmiotowej diagnozy, „każdy realny krok ku przezwyciężeniu tej sprzeczności traktowałbym jako autentyczne osiągnięcie środowiska i jego piśmiennictwa"1. Taki też krok w Odpowiedzialności posłów i senatorów na tle zasady mandatu wolnego został postawiony.

Wspomnieć trzeba o warstwie metodologicznej recenzowanej monografii. Autor przeprowadza kompleksową analizę aktualnie obowiązujących uregulowań konstytucyjnych, ustawowych i podstawowych w zakresie materialnych przesłanek odpowiedzialności parlamentarzystów. Z tych względów główną metodą badawczą wykorzystywaną w publikacji jest metoda dogmatyczna, uzupełniona metodami porównawczą i historyczną. Uwzględnia praktykę parlamentarną, a nawet szerzej - praktykę stosunków politycznych, w tym przede wszystkim faktyczne warunki wykonywania mandatu parlamentarnego. Jak sam podkreśla, zwrócenie uwagi na współczesne realia wypełniania funkcji deputowanego jest warunkiem sine qua

W. Sokolewicz, „Przegląd Sejmowy” w latach 2003-2008 (artykut recenzyjny), „Państwo i Prawo” z. 2, 2009, s. 109. 
non realizacji zadania w postaci zbadania odpowiedzialności parlamentarzystów (s. 17).

Jak zaznacza Krzysztof Grajewski (s. 11), odpowiedzialność parlamentarzysty nie może być rozpatrywana w oderwaniu od zasady suwerenności, a co za tym idzie, kwestii reprezentacji i koncepcji mandatu przedstawicielskiego. Szczególne znaczenie ma przy tym konstrukcja mandatu wolnego wyrażona w przepisach Konstytucji RP z 2 kwietnia 1997 r. Wynika to stąd, że wszelkie rodzaje odpowiedzialności deputowanego, w tym zasadniczo odpowiedzialność i związki łączące parlamentarzystę z wyborcami, jak również zachodzące między nim i frakcją parlamentarną, do której należy muszą być plasowane i rozpatrywane właśnie w kontekście konstrukcji tego mandatu. Tym samym dwa wymiary, $\mathrm{z}$ jednej strony motyw mandatu parlamentarnego, a z drugiej strony odpowiedzialność posłów i senatorów, wyznaczają osie konstrukcyjne publikacji, ramy, którym podporządkowane zostały rozważania szczegółowe.

Krzysztof Grajewski wydziela i poddaje analizie różne aspekty odpowiedzialności ponoszonej przez polskich parlamentarzystów: polityczną, konstytucyjną, regulaminową, karną i cywilną. Czyni to w sposób systematyczny, z najwyższą starannością dbając o przejrzystość budowanej argumentacji. Szczególne walory heurystyczne należy przypisać wywodom Autora poświęconym politycznej odpowiedzialności parlamentarzystów. Dotyczy ona sedna mandatu przedstawicielskiego jako podstawy szeroko rozumianych rządów demokratycznych. W nawiązaniu do rozważań prowadzonych pod koniec XVIII w. we Francji i kontynuowanych w okresie późniejszym, Krzysztof Grajewski przyjmuje, że zasada reprezentacji politycznej oznacza udzielenie przez wyborców wybranym przez siebie przedstawicielom mandatu do wyrażania ich woli, a wola wyrażana przez reprezentantów na forum parlamentu, przyjmująca postać konkretnych rozstrzygnięć organu przedstawicielskiego, jest następnie „zarachowywana” na rzecz suwerena. Poprzez wybór do składu organu przedstawicielskiego zawiązuje się między reprezentantem a wyborcami swoista więź prawna polegająca na tym, że staje się on przedstawicielem wszystkich lub tylko niektórych wyborców. Z kolei odpowiedź na pytanie: czy jest przedstawicielem wszystkich wyborców czy tylko niektórych z nich, powiązać należy z dwiema prymarnymi konstrukcjami mandatu parlamentarnego: mandatem imperatywnym i wolnym. 
Szczególną uwagę poświęca K. Grajewski uchwyceniu istoty współczesnego mandatu wolnego. Ukazuje go na tle mandatu imperatywnego (w tym tzw. mandatu socjalistycznego), genezy i ewolucji mandatu wolnego jako takiego. Za cechy kluczowe mandatu wolnego przyjmuje niezależność i nieodwoływalność członka organu przedstawicielskiego.

Konfrontacja bieżących uwarunkowań funkcjonowania parlamentarzysty $\mathrm{w}$ jego otoczeniu $\mathrm{z}$ konstytucyjnymi uprawnieniami członka organu przedstawicielskiego wynikającą $\mathrm{z}$ piastowanego mandatu wolnego może powodować pewne zamieszanie u samych parlamentarzystów. U podstawy zakłopotania leży wielość i różnorodność relacji, w których działa przedstawiciel. Jest tak $\mathrm{z}$ tego powodu, że faktyczne sprawowanie mandatu przedstawicielskiego jest $\mathrm{w}$ rzeczywistości determinowane łącznie interesem suwerena oraz interesami poszczególnych grup lub indywidualnych wyborców, a także - a może przede wszystkim - ugrupowań politycznych. Obok determinanty prawnej sprawowania mandatu przedstawicielskiego, wykluczającej imperatywną konstrukcję mandatu oraz zawierającą dyrektywę czynienia wszystkiego dla dobra obywateli, istnieją również determinanty polityczne, bez których nie można prawidłowo skonkretyzować istoty współczesnego mandatu parlamentarnego. Sfera stosunków socjologiczno-politycznych w znacznym stopniu wpływa na faktyczną pozycję parlamentarzysty, a także jest istotną determinantą jego działalności zarówno na wewnątrz, jak i na zewnątrz parlamentu.

Parlamentarzysta nie funkcjonuje w przestrzeni wolnej od społecznych oddziaływań, czy nawet nacisków, ale - jak słusznie zaznacza Autor - w jeszcze większym zakresie możliwość wpływania na działalność parlamentarzysty posiada macierzysta partia polityczna, jak i klub parlamentarny, którego jest członkiem. Nie można nie docenić uprawnień partii politycznych przede wszystkim w procedurze wyborczej oraz w kontekście funkcjonowania organizacji zrzeszającej deputowanych partii na forum parlamentu (frakcji parlamentarnej). Oczywistym zjawiskiem jest dominująca pozycja partii politycznych w procedurze zgłaszania kandydatów w wyborach parlamentarnych. Znaczenie partii politycznych uwidacznia się również $\mathrm{w}$ trakcie trwania kadencji, przede wszystkim poprzez kierowanie działalnością frakcji parlamentarnej, która dysponuje środkami prowadzącymi do dyscyplinowania swoich członków. Przynależność frakcyjna kształtuje zachowania 
polityczne reprezentanta, przesądza o stanowiskach zajmowanych przez niego w debatach politycznych.

Za ustaleniami doktryny ${ }^{2}$ K. Grajewski przyjmuje, że ugrupowania polityczne i ich frakcje parlamentarne artykułują interes narodowy według przekonania, że właśnie każde z nich odczytuje interes ogółu i zamierza go realizować jak najlepiej. Wybierając kandydatów danej partii, wyborca wie, jak rozumiany interes ogółu będzie realizowany, jeśli dana partia zdobędzie większość. Wątek stosunków deputowanego z partią polityczną widzi także w kontekście konstytucyjnej pozycji partii politycznych. Podkreśla, że analizując zagadnienie mandatu wolnego nie można zapominać o tych przepisach konstytucji, które regulują status oraz zasady i cele działalności partii politycznych. To one są gwarancją rzeczywistego uczestnictwa członków zbiorowego podmiotu suwerenności w sprawowaniu władzy państwowej. Partie artykułują, reprezentują i bronią interesów społecznych, a także uczestniczą w realizacji władzy zwierzchniej w państwie, przez co stały się nieodłącznym elementem parlamentaryzmu. A zatem, przekonująco dowodzi Autor Odpowiedzialności posłów i senatorów..., związków łączących parlamentarzystę z frakcją parlamentarną nie można redukować do motywu tzw. mandatu wolnego, ale trzeba widzieć w szerokim spektrum znaczenia partii politycznych dla systemu politycznego państwa. Jeśli parlamentarzysta bierze pod uwagę opinie lub postulaty partii politycznych tudzież wyborców, to nie dlatego, że jest zobowiązany do realizacji jakichkolwiek konkretnych opinii, postulatów czy nakazów, ale dlatego, że uważa je za słuszne i godne realizacji, tudzież poparcia na forum organu przedstawicielskiego.

Z kolei nieodwoływalność członka organu przedstawicielskiego postrzega Autor jako prawny zakaz odwoływania deputowanego w trakcie kadencji przez wyborców oraz zakaz pozbawiania mandatu przedstawicielskiego przez jakikolwiek organ państwowy, w tym zakaz wykluczenia go ze składu izby przez sam parlament $\mathrm{z}$ przyczyn związanych z polityczną oceną sprawowania mandatu przedstawicielskiego przez parlamentarzystę. Słusznie przy tym dodaje, że analizowana zasada nie wyklucza istnienia przyczyn wygaśnięcia mandatu z powodów niezwiązanych z oceną działalności danej osoby w charakterze członka organu przedstawicielskiego. Możliwe jest

2 M.Kruk, Koncepcja mandatu przedstawicielskiego w konstytucyjnej doktrynie i praktyce, „Przegląd Sejmowy” nr 4, 1993. 
zatem wygaśnięcie mandatu tak ze względów losowych, naruszenia zasady incompatibilitas czy chociażby z powodów zależnych od woli deputowanego.

W kontekście motywów utraty mandatu parlamentarnego, poważne wątpliwości Autora (s. 91) budzi (praktykowana w niektórych państwach współczesnych) dopuszczalność utraty mandatu jako skutek zmiany przynależności frakcyjnej członka parlamentu. Powoduje ona daleko idące uzależnienie deputowanego od partii, z ramienia której ubiegał się o mandat parlamentarny, jak również frakcji parlamentarnej, w ramach której dotychczas działał w parlamencie. K. Grajewski uznaje, że tego typu możliwość w istocie rzeczy wprowadza odpowiedzialność prawną przed partią polityczną za wystąpienie z jej szeregów. Taką odpowiedzialność przed partią traktuje jako naruszającą konstrukcję mandatu wolnego. $Z$ tego też powodu nie budzi ona wątpliwości co do jej formalnej zgodności z konstytucją jedynie wtedy, gdy jest expressis verbis przewidziana przez przepisy konstytucyjne (s. 91).

Kolejne partie Odpowiedzialności posłów i senatorów... poświęcone są charakterystyce odpowiedzialności konstytucyjnej, karnej i dyscyplinarnej parlamentarzysty. Problematyka odpowiedzialności karnej nie jest nową dla Autora. Jest on znany z licznych publikacji z tego zakresu, $w$ tym monografii Immunitet parlamentarny $w$ prawie polskim ${ }^{3}$. Przedmiotowe zainteresowania badawcze znajdują sui generis podsumowanie w recenzowanej monografii. Na równie najwyższe uznanie zasługują rozważania Autora poświęcone odpowiedzialności konstytucyjnej i dyscyplinarnej parlamentarzysty. Są one kompletne, a przy tym precyzyjnie skonstruowane i logicznie uzasadnione.

Podsumowując, monografia Odpowiedzialność posłów i senatorów na tle zasady mandatu wolnego to udane podsumowanie prowadzonych w Polsce badań nad istotą mandatu parlamentarnego. Należy ją traktować jako istotny wkład do teorii prawa konstytucyjnego, godną polecenia tym wszystkim, którzy interesują się przedmiotową dziedziną prawa, jak również naturą rządów demokratycznych.

Jacek Zaleśny

(Uniwersytet Warszawski)

3 K. Grajewski, Immunitet parlamentarny w prawie polskim, Warszawa 2001. 